\title{
Reestablishment of the genus Sampaiella J.C. Gomes (Bignoniaceae) ${ }^{\mathbf{1}}$
}

\author{
MILENE M. SILVA-CASTRO ${ }^{2,4}$, ANA M. GIULIETTI ${ }^{3}$ and FRANCISCO A.R. DOS SANTOS ${ }^{3}$
}

(received: August 6, 2003; accepted: September 9, 2004)

\begin{abstract}
Reestablishment of the genus Sampaiella J.C. Gomes (Bignoniaceae)). Bignonia trichoclada DC. was originally described from flowering material, later being transferred to Arrabidaea as Arrabidaea trichoclada (DC.) Bureau \& K. Schum. Gomes placed it in a monotypic genus Sampaiella, on account of its tomentose indumentum of branched hair and reticulate pollen grains. Sandwith placed Sampaiella in synonymy of Arrabidaea, the fruit of Sampaiella at that time being still unknown. The recent discovery of fruiting material enable the authors to distinguish Sampaiella from Arrabidaea on the basis of fruit and pollen characters. Sampaiella has a linear-oblong capsule with three inconspicuous ribs and a winged margin, quite distinct from the fruit type of Arrabidaea. The pollen is reticulate in Sampaiella, and is different from the microreticulate pollen found in Arrabidaea. These characters support the reestablishment of the genus Sampaiella J.C. Gomes, but leave unanswered its true relationships, which can hopefully be resolved by molecular studies.
\end{abstract}

Key words - Arrabidaea, Bignoniaceae, Bignonieae, Cuspidaria, Sampaiella

RESUMO - (Restabelecimento do gênero Sampaiella J.C. Gomes (Bignoniaceae)). Bignonia trichoclada DC. foi descrita a partir de material florífero e posteriormente foi transferida para Arrabidaea trichoclada (DC.) Bureau \& K. Schum. Gomes posicionou-a no gênero monotípico Sampaiella especialmente pelo indumento tomentoso com tricomas dendríticos e grãos de pólen reticulados. Sandwith sinonimizou Sampaiella em Arrabidaea, mesmo desconhecendo os frutos. A recente descoberta de material frutífero permitiu caracterizar a espécie como tendo cápsula linear-oblonga, com três costelas inconspícuas e margem com alas, bastante distinta da cápsula de Arrabidaea. Os grãos de pólen de Sampaiella apresentam escultura reticulada, diferente da escultura microrreticulada de Arrabidaea. Devido a essas características diferenciais, é proposto o restabelecimento de Sampaiella J.C. Gomes, mas ainda deixa sem resposta seu verdadeiro relacionamento, que provavelmente poderá ser resolvido por estudos moleculares.

Palavras-chave - Arrabidaea, Bignoniaceae, Bignonieae, Cuspidaria, Sampaiella

\section{Introduction}

The family Bignoniaceae consists of about 120 genera, divided into eight tribes with a pantropical distribution (Gentry 1980). Within Brazil, four tribes are recorded as native: Bignonieae, Crescentieae, Schlegelieae and Tecomeae. The tribe Bignonieae is chiefly characterized by the possession of a capsule with septifragal dehiscence (dehiscence parallel to the septum). According to Gentry (1980), the tribe includes about 50 genera, of which 45 and about 269 species occur in Brazil. Around 100 of these species belong to Arrabidaea, which is the largest genus in the tribe. By contrast, the majority of genera, belonging to the Bignonieae, contain few species or are monotypic. With

1. Part of M.M Silva-Castro's M.Sc. thesis, Post-graduate Studies in Plant Biology, Universidade Federal da Bahia (UFBA).

2. Universidade Estadual do Sudoeste da Bahia, Departamento de Ciências Biológicas, Rua José Moreira Sobrinho, s/n, Jequiezinho, 45206-510 Jequié, Bahia, Brasil.

3. Universidade Estadual de Feira de Santana, Departamento de Ciências Biológicas, BR 116, km 03, Campus Universitário, 44031-460 Feira de Santana, Bahia, Brasil.

4. Corresponding author: milenecastro@ig.com.br many species and even genera of Bignonieae having been described from incomplete material, it is increasingly difficult to verify generic characters within the group; a revision of generic limits is thus becoming ever more urgent.

The history of Sampaiella began in the $19^{\text {th }}$ century, when De Candolle (1838) described Bignonia trichoclada, based on flowering material, collected by Martius in the caatingas of Minas Gerais. Subsequently, this species was included in Arrabidaea by Bureau \& Schumann (1896), under the new combination: Arrabidaea trichoclada (DC.) Bureau \& K. Schum. Later, Gomes (1949) removed it from Arrabidaea, creating a monotypic genus Sampaiella with the single species: S. trichoclada (DC.) J.C. Gomes. Diagnostic characters used by this author, to distinguish it from Arrabidaea, included the tomentose indumentum, with dendritic trichomes and the reticulate pollen exine. Nevertheless, Sandwith (1968) disagreed with this proposal, and reduced Sampaiella to a synonym under Arrabidaea, considering that both the hair type and the tricolporate, reticulate pollen, fell within the morphological range of Arrabidaea. The recent collection of both flowering and fruiting material of this 
species, has reopened the question as to the true position of Sampaiella. This is the subject of the present paper, in which various other species of both Arrabidaea and Cuspidaria were examined and compared.

\section{Material and methods}

The specimens for the present study were mainly collected in the Chapada Diamantina, Bahia, Brasil, during a regional survey of the genus Arrabidaea. The Chapada Diamantina, the northern, Bahian part of the Espinhaço Range, extends from the Serra de Jacobina $\left(10^{\circ} \mathrm{S}\right.$ and $\left.40^{\circ} 10^{\prime} \mathrm{W}\right)$, in the north, to Rio de Contas and Livramento de Nossa Senhora $\left(13^{\circ} 31^{\prime} \mathrm{S}\right.$ and $\left.41^{\circ} 57^{\prime} \mathrm{W}\right)$, in the south. It covers an area of around $38,000 \mathrm{sq}$. $\mathrm{km}$, with altitudes ranging from between 800 and $1,200 \mathrm{~m}$ above sea level, and with annual rainfall varying from about 800 to $1,200 \mathrm{~mm}$. The dry season is during winter (May to September) and the rainy season during summer (November to March). Due to regional variation in relief and climate, various vegetation types are established in different altitudinal zones. Caatinga vegetation occurs in lowland areas, different forest types on the mountain slopes, and, culminating in the upper levels, the more open vegetation of Cerrado and Campo Rupestre (Funch 1999, Giulietti et al. 1996, Harley 1995). While species of Arrabidaea were encountered in all the vegetation types mentioned above, Sampaiella trichoclada was collected solely in Caatinga and Dry forest. All the material examined has been deposited in the herbarium of the University of Feira de Santana (HUEFS), except when cited from other herbaria. A morphological study of a range of species, listed below, from the rich material available in the various herbaria, was undertaken, and from these a selection was made for studies trichomes and pollen. The species selected for further study included: Arrabidaea brachypoda (DC.) Bureau, B.L. Stannard PCD2302; A. candicans (L.C. Rich.) DC., W. Ganev 2717; A. celastroides Bureau \& K. Schum., F. França 3042, E. Melo et al. 1172; A. cinerea Bureau \& K. Schum., A.A. Conceição PCD2209; A. craterophora (DC.) Bureau, W. Ganev 1603; A. cuneifolia (DC.) Sandwith, W. Ganev 1742; A. harleyi A.H. Gentry ex M.M. Silva \& L.P. Queiroz, W. Ganev 319; A. limae A.H. Gentry, E.B. Miranda-Silva 311; A. parviflora (Mart. ex DC.) Bureau \& K. Schum., W. Ganev 1121; A. pulchra (Cham.) Sandwith, W. Ganev 98; A. rego (Vell.) DC., J.C. Lima 312; A. sceptrum (Cham.) Sandwith, M.M. Silva 95; A. selloi (Spreng.) Sandwith, M.M. Arbo 7433; A. aff. simplex A.H. Gentry, M.M. Silva 216; Sampaiella trichoclada (DC.) J.C. Gomes, W. Ganev 1025 (fl.), E. Melo et al. 2744 (fl., fr.), G. Hatschbach 44126 (fl.) (CEPEC, MBM), G. Hatschbach \& F.J. Zelma 50496 (fl., fr. young) (MBM) and J.A. Lombardi 2099 (fl.) (MBM). To complement these studies, the following material was also selected for a study of dendritic trichomes: Arrabidaea cinnamomea (DC.) Sandwith, S. Romaniuc Neto et al. 626 (SP) and A. dispar Bureau \& K. Schum.,
G. Hatschbach 44133, W.W. Thomas et al. 9573 (MBM), and Cuspidaria lasiantha (Bureau \& K. Schum.) A.H. Gentry, L.P. Queiroz 1308 (HUEFS), for a comparison of capsules with winged margins.

The method of Jeffrey (Johansen 1940) was used to separate trichomes from the epidermis, for examination. For pollen grain analysis, the acetolysis method, described by Erdtmann (1960), was used.

\section{Results and Discussion}

Characterization of the taxon: scandent shrubs to $3 \mathrm{~m}$ high, with branches, leaves and flowers densely tomentose, with multicellular, dendritic hairs and multicellular, peltate hairs (figures 1, 3, 20,21). Leaves trifoliolate, leaflets ovate, coriaceous, the lateral leaflets asymmetric (figure 2). Inflorescence a terminal thyrse, with co-inflorescences in a dichasium. Calyx rusty, greenish, coriaceous, campanulate, 5-lobed (figure 4); corolla greenish-white, coriaceous, funnel-shaped, externally tomentose in the upper $2 / 3$, and glabrous in the lower $1 / 3$. Stamens didynamous, staminode reduced (ca. $7 \mathrm{~mm}$ long); nectariferous disc annulate, ovary bicarpellate, densely glandular, with 24 ovules in two series of twelve (figures 6,7). Capsule septifragal, 20-23 $\times 2 \mathrm{~cm}$, oblong-linear, black on drying, valves coriaceous to woody, each with three prominent ribs, apex of capsule acute, mucronulate, base cuneate, margins winged, straight, with wings $2 \mathrm{~mm}$ wide (figures 8, 9). Seeds ca. $3.5 \times 1.5 \mathrm{~cm}$, seed-chamber chestnut brown, wings hyaline (figures 10,11$)$. Pollen in monads, grains large $(63 \times 53 \mu \mathrm{m})$, isopolar, subprolate $(\mathrm{P} / \mathrm{E}=1.19)$; triaperturate, apertural membrane characteristically torn near equatorial region, colpus with margin; exine (ca. $5.1 \mu \mathrm{m}$ ) semitectate, with columellae long, evident; reticulum heterobrocate with walls simply columellate, sinuous and, sometimes, interrupted, tectum thick (ca. $1.7 \mu \mathrm{m}$ ), sexine thicker than nexine. Mesocolpus with lumina of reticulum broad and irregular, showing sexine elements inside; lumina reduced in size in apocolpus region, and more homogeneous in shape (figures 16, 18).

The vegetative and reproductive characters of the specimens examined, agree closely with those listed by De Candolle (1838), for Bignonia trichoclada DC., and for Arrabidaea trichoclada (DC.) Bureau \& K. Schum. by Bureau \& Schumann (1896). The discovery of fruiting material, indicates that this taxon should not be included in Arrabidaea, which is characterized by a linear, flattened capsule, with unwinged margins and with a single median rib along each valve. In the tribe 


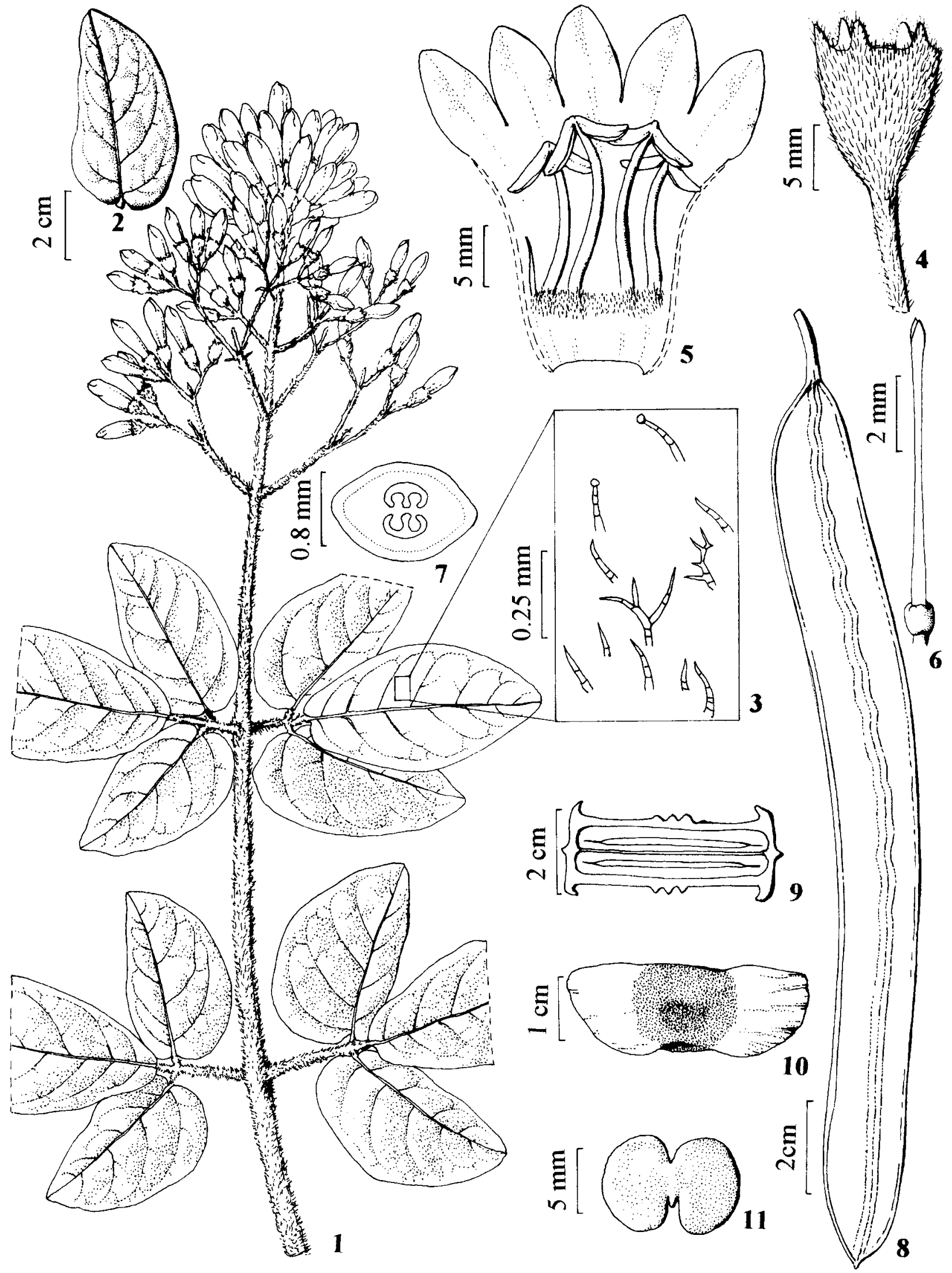

Figures 1-11. Sampaiella trichoclada.1. Habit. 2. Leaflets. 3. Leaf indumentum 4. Calyx. 5. Corolla opened to show androecium. 6. Gynoecium. 7. Transverse section of ovary. 8. Fruit. 9. Transverse section of fruit. 10. Seed. 11. Embryo. (Melo et al. 2744). 
Bignonieae, three genera, Cuspidaria, Piriadacus and Adenocalymma also contain species with winged fruit. However the fruits of these genera possess broader wings, varying from $5-10 \mathrm{~mm}$ wide, and there is only a single rib per valve. Apart from these differences, Adenocalymma has a creamy yellow to golden yellow corolla, and extra-floral nectaries; Piriadacus has a pink to orange corolla and exserted stamens; Cuspidaria

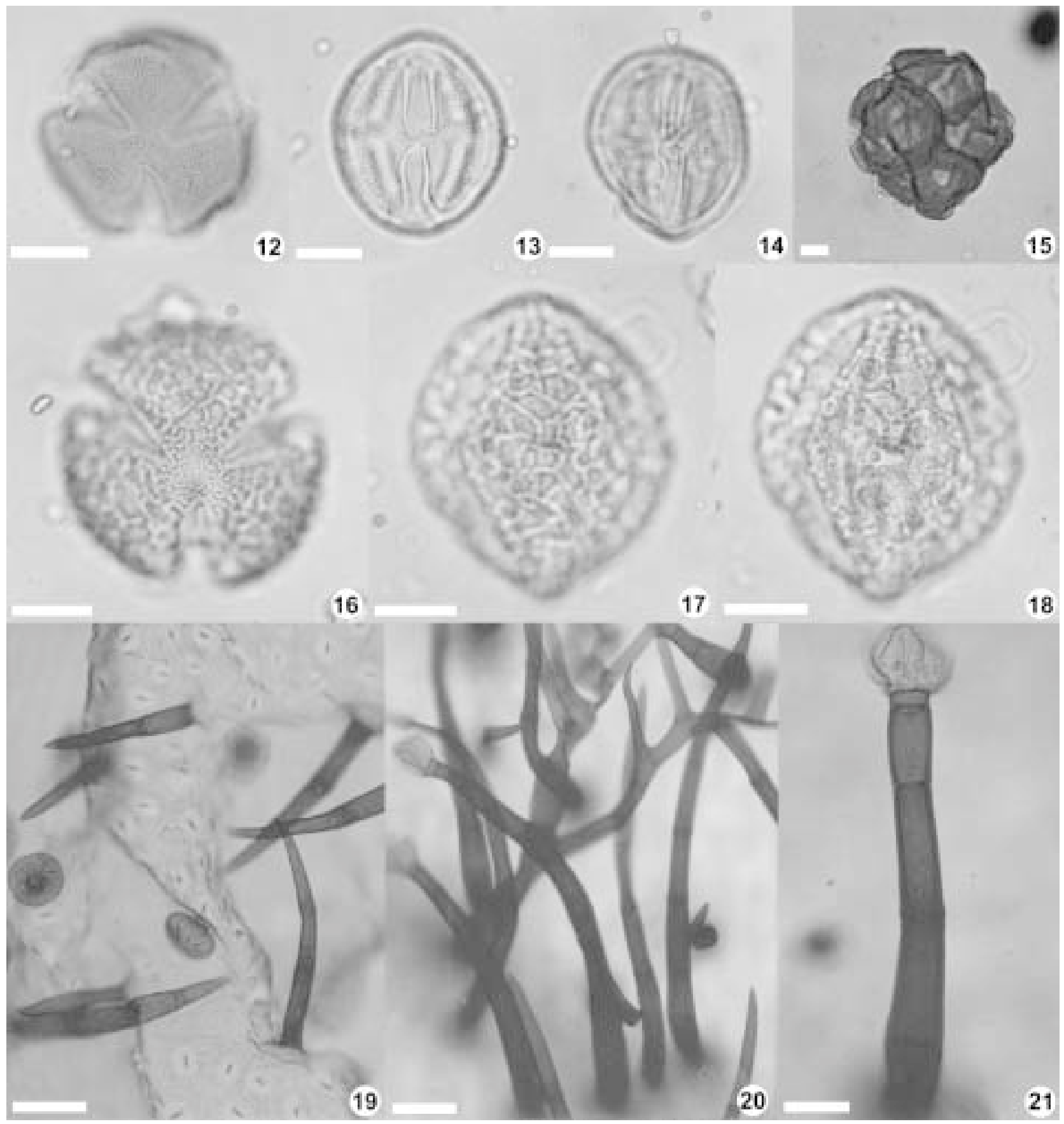

Figures 12-14. Pollen grains. 12. Arrabidaea cinerea. 13. A. cinnamomea. 14. A. dispar. 15. Cuspidaria lasiantha. 16-18. Sampaiella trichoclada. Figures 19-21. Trichomes. 19. Arrabidaea selloi. 20-21. Sampaiella trichoclada. (12: Conceição PCD 2209; 13: Romaniuc Neto et al. 626; 14: Thomas et al. 9573; 15: Queiroz 1308; 16-18, 20, 21 Melo et al. 2744; 19: Arbo 7433). Bars $=10 \mu \mathrm{m}(12-18), 50 \mu \mathrm{m}(19-21)$. 
has pollen in tetrads. It therefore seems improbable that these genera could accommodate the taxon here under consideration.

Within the Bignonieae, the delimitation of genera has still not been resolved, though pollen grain characters have been shown to be taxonomically important (Burmman 1977, Gentry \& Tomb 1979, Bove 1992). The pollen of Arrabidaea are in monads, triaperturate, with exine microreticulate, the microreticulum homobrocate to psilate, medium to large, spheroid to prolate (figures 12-14). In Cuspidaria, based on $C$. lasiantha (Bureau \& K. Schum.) A.H. Gentry, the pollen is in tetrads and shows a microreticulate exine (figure 15). Gomes justified the erection of Sampaiella, on the grounds that the pollen was in monads with exine reticulate and reticulum heterobrocate.

All specimens of $S$. trichoclada so far examined show these characteristics (figure 16). The consistency of pollen characteristics, within each of the three genera examined, reinforces the recognition of Sampaiella as a distinct genus, as proposed by Gomes (1949).

The other character, diagnostic of Sampaiella, as proposed by Gomes (1949), is the presence of an indumentum of multicellular, dendritic hairs. Although a striking feature of this taxon, the same character was also observed in Arrabidaea cinnamomea (DC.) Sandwith and A. dispar Bureau \& K. Schum.

These species, however, show pollen with microreticulate exine (figures 13, 14). Their taxonomic position remains doubtful, as no fruiting material is known.

On the basis of the above studies, it is concluded that Sampaiella trichoclada (DC.) J.C. Gomes should be reestablished, due to its distinctive fruit and pollen morphology, which is not in accord with its placement in either Arrabidaea or in Cuspidaria.

Although at present Sampaiella is proposed here as a monotypic genus, represented by the single species S. trichoclada (DC.) J.C. Gomes, we consider it probable that other species may in due course be incorporated. This will require a fuller understanding of the species now included in Arrabidaea, and examining, among others, the fruiting characters of such Bignonieae that show similarities in flower and leaf with the species under consideration here. We also consider it essential that a full phylogenetic study of the Bignonieae be carried out, combining both morphological and molecular data, so that monophyletic groups can be defined.

Sampaiella trichoclada occurs widely from Piauí, as evidenced by the collection: Luetzelburg 1225
(Gomes 1949), south to São Paulo (see Barreto 2484 in www.mobot.org), ocurring, in NE Brazil, in areas of caatinga in sandy soil. Flowering material was collected in July and November and fruiting material in April.

Acknowlegements - The authors wish to thank Engenheiro Florestal Carlos Eduardo Santos, for his help in locating a copy of Gomes (1949), Ivan Farias Castro for the plate of Sampaiella, Raymond M. Harley for the translation and taxonomic advice, the two referees and editors for useful suggestions and to CNPq for the research grants for A.M. Giulietti and F.A.R. dos Santos.

\section{References}

BOVE, C.V. 1992. Catálogo sistemático do pólen das plantas arbóreas do Brasil Meridional. XXV- Bignoniaceae. Revista Brasileira de Biologia 52:283-292.

BUREAU, L.E. \& SCHUMANN, K.M. 1896. Bignoniaceae. In Flora brasiliensis (C.F.P. Martius \& A.G. Eichler, eds.). F. Fleisher, Lipsiae, v.8, pars 2, p.1-451.

BURMMAN, J. 1977. Pollen morphology of the Bignoniaceae. Pollen et Spores 19:447-579.

DE CANDOLLE, A.P. 1838. Revue sommaire de la famile des Bignoniacées. Bibliothèque Universelle de Gèneve, Gèneve. p.1-24.

ERDTMANN, G. 1960. The acetolysis method. A revised description. Svensk Botanisk Tidskrift. 39:561-564.

FUNCH, R. 1999. A visitor's guide to the Chapada Diamantina mountains. Secretaria de Cultura e Turismo, Salvador.

GENTRY, A.H. 1980. Bignoniaceae. Part I. Tribes Crescentieae and Tourrentieae. Flora Neotropica Monograph 25:1-130.

GENTRY, A.H. \& TOMB, A.S. 1979. Taxonomic implications of Bignoniaceae palynology. Annals of the Missouri Botanical Gardens 66:756-777.

GIULIETTI, A.M., QUEIROZ, L.P. \& HARLEY, R.M. 1996. Vegetação e flora da Chapada Diamantina, Bahia. In Anais da $4^{\text {a }}$ Reunião especial da SBPC (A. Malavasi, ed.). Sociedade Brasileira para o Progresso de Ciências, Feira de Santana, p.144-156.

GOMES, J.C. 1949. Contribuição à sistemática das Bignoniaceae Brasileiras I. Sampaiella J. C. Gomes, Nov. Gen. Rodriguésia 12:107-111.

HARLEY, R.M. 1995. Introduction. In Flora of the Pico das Almas, Chapada Diamantina, Bahia, Brazil (B.L. Stannard, ed.) Royal Botanic Gardens, Kew, p.1-40.

JOHANSEN, D.A. 1940. Plant microtechnique. McGraw-Hill, New York.

SANDWITH, N.Y. 1968. Contributions to the Flora of Tropical America LXXVI: Notes on Bignoniaceae XXIV: Arrabidaea "Flora Brasiliensis" and subsequently. Kew Bulletin 22:403-420. 